Revista Iberoamericana, Vol. LXXX, Núm. 247, Abril-Junio 2014, 493-510

\title{
MONSIEUR PAIN O LOS COMIENZOS DE UN ESCRITOR MELANCÓLICO
}

\author{
POR \\ Paula Aguilar \\ Universidad Autónoma de Entre Ríos
}

\begin{abstract}
Una generación que todavía había ido a la escuela en tranvía tirado por caballos, se encontró súbitamente a la intemperie, en un paisaje en que nada había quedado incambiado a excepción de las nubes. Entre ellas, rodeado por un campo de fuerza de corrientes devastadoras y explosiones, se encontraba el minúsculo y quebradizo cuerpo humano.
\end{abstract}

Walter Benjamin

Soñábamos con utopía y nos despertamos gritando. Roberto Bolaño

Hoy sufro suceda lo que suceda. Hoy sufro solamente. César Vallejo

Monsieur Pain, la novela de Roberto Bolaño que la editorial Anagrama publica en 1999, nace con el título La senda de los elefantes en 1981 o 1982, como el mismo autor explica en la "Nota preliminar". Es una novela de los comienzos por dos razones. Forma parte de los inicios de Bolaño como escritor que intenta profesionalizarse entre concursos y "premios búfalo que un piel roja tenía que salir a cazar pues en ello le iba la vida" (12). También se constituye como una novela de los comienzos en el sentido que desarrolla Edward Said en Beginnings: Intention and Method. Monsieur Pain condensa temas, tonos, intenciones que Bolaño retomará y desplegará en narrativas posteriores. En esta novela se anuncia y da nacimiento al escritor melancólico de los noventa y crea un precursor: el escritor derrotado, el héroe fracasado de la lucha republicana, en el melancólico César Vallejo. Bolaño se pregunta sobre la condición del escritor luego del fracaso del gobierno de Allende, para ello la novela convoca la Guerra Civil española y anticipa el nazismo que asolará a Europa. La relación de Bolaño con la historia de la literatura latinoamericana -y con la historia a secas- es una preocupación constante. Gonzalo Aguilar bien describe un tono melancólico, contra el "entusiasmo" de las 
narrativas del boom. Para Bolaño "ya no emana ninguna autoridad ni de la literatura, ni de los escritores" (Aguilar 148), en tanto pertenece a un campo literario signado por la violencia y la barbarie de las últimas dictaduras latinoamericanas.

Leer Monsieur Pain como texto de los comienzos a la luz de otros textos del autor chileno supone un volver atrás, como "el primer paso en la producción intencional de sentido" que se descubre a posteriori. Es decir, para un análisis de esta novela como texto de los comienzos es necesario primero la lectura de las novelas y cuentos que siguieron en el tiempo a Monsieur Pain y conforman un proyecto creador que interviene en el contexto de debates en torno a las herencias de las últimas dictaduras en el Cono Sur.

La trama temporal, de la enunciación al enunciado, evoca la pérdida de la utopía occidental en el siglo xx. Se inicia la intriga con una misión que el mesmerista Pierre Pain debe cumplir por pedido de su amiga Madame Reynaud: utilizar sus conocimientos de acupuntura y pases de energía para curar a un enfermo sudamericano, desahuciado, que agoniza sin una explicación lógica, “¡Todos los órganos son nuevos! ¡Ojalá que encontráramos uno en mal estado! Veo que este hombre se muere, pero no sé de qué” (59), asevera el eminente doctor Lemiére. César Vallejo agoniza y su única comunicación con la realidad reside en el constante hipo que parecía llenar de agujeros el silencio (62). Lo extraño del caso se acentúa cuando Pain, antes de tomar una decisión sobre el asunto, recibe la visita de dos españoles de aspecto sospechoso que lo sobornan para olvidar el tema y dejar todo en la nada. Así, se inicia un nebuloso recorrido en el cual Pain intentará confesarle su amor a Madame Reynaud, salvarle la vida a Vallejo y descubrir por qué quieren impedírselo. Su relato nos lleva por un camino que parece armado de pasillos laberínticos, lluviosos, oscuros, solitarios, entre el delirio, los sueños y lo real hasta concluir en el fracaso profesional y personal. Una derrota que, enmarcada en un contexto tumultuoso, figura las derrotas históricas que han sufrido varias generaciones durante el siglo xx.

La novela comienza entonces ubicándonos en tiempo y espacio: París, 1938, precisamente un miércoles lluvioso de otoño, 6 de abril, al atardecer. Estas marcas temporales -y climáticas- van a hilar todo el texto como constantes de una trama que se figura caótica, entre misteriosa y delirante. El relato en primera persona abarca el mes de abril, bajo la lluvia infinita, en una ciudad vacía y gris. Un espacio urbano desolado y amenazante, tan cerrado como los otros espacios de la novela, por ejemplo el cine, el almacén de trastos inútiles y la clínica, por los que el personaje y narrador Pierre Pain transita intentando resolver el enigma al que lo han arrojado su joven amiga Madame Reynaud, Georgette Vallejo y un grupo de españoles sombríos y que parecen recién salidos de la cárcel o de un sótano (20). Son diversos elementos los que, reiterados a lo largo del texto, le dan al mismo una cadencia monótona, una atmósfera sombría. Nos introducen en la melancolía misma y, a la vez, nos mantienen alerta, con la extraña sensación de que algo raro va a suceder.

\footnotetext{
Revista Iberoamericana, Vol. LXXX, Núm. 247, Abril-Junio 2014, 493-510 ISSN 0034-9631 (Impreso) ISSN 2154-4794 (Electrónico)
} 
LOS LUGARES DE LA MEMORIA Y “LO REAL FANTÁSTICO”

Pierre Pain atraviesa por tres experiencias de la memoria; cada una en un espacio diferente. Estos lugares devienen zonas de búsqueda y revelación y, en el cruce entre lo real y lo onírico, invocan a los fantasmas del pasado de Pierre Pain, que constantemente reaparecen en sus pesadillas.

La sala cinematográfica es la más significativa pues el episodio en el cine es una puesta en abismo del eje de la novela. El cine concentra características que comparten los otros espacios: una oscuridad que parpadea, por la iluminación irregular de la pantalla, y la sensación de que algo extraño puede ocurrir (“... el acomodador carraspeó al pasar junto a mí, como si pretendiera advertirme de algo fuera de lo normal” [120]). Pain llega a la sala cuando persigue a uno de los españoles y se encuentra con un viejo mesmerista conocido, Pleumeur-Bodou, devenido fascista. La película que están proyectando, titulada Actualidad, reúne un relato ficcional en torno a las peripecias del personaje Michel y el fragmento de un documental sobre un grupo de estudiantes en un laboratorio, constituyendo un "híbrido de documental" (128). Es "una historia de amor y ciencia” (116), cuyos diálogos remiten a la cuestión de la memoria, en una trama donde las nuevas promesas de la ciencia ensayan algo relacionado con la radioactividad, luego ocurre una explosión y se desata un asesinato en masa fríamente planeado (130). En Michel hay un pasado oscuro, una culpa que lo oprime aunque él exprese su inocencia; ha padecido una experiencia traumática y está atrapado entre el olvido y las pesadillas: "Durante el día la amnesia es como el desierto. Durante la noche es como la selva, poblada de fieras salvajes” (121). Se plantea también el problema de la identidad articulada al recuerdo, "La pesadilla es el pasado, la memoria; para olvidar tendría que ser otro" (122, énfasis mío). Alternado con la historia de Michel, el documental sobre el grupo de jóvenes científicos tiene como participante a Terzeff, un viejo amigo de Pain. Así, Pierre Pain ya no es un mero espectador, hay una parte de su propia historia que aparece en la pantalla, algo que tiene que ver con su pasado. Después de asistir al cine, Pain enfrenta a Pleumeur-Bodou. El entonces amigo es ahora colaborador nazi y se jacta de utilizar la técnica del mesmerismo como instrumento de tortura. Como en el film, Pain también se encuentra atrapado en las tramas de la memoria, en un recuerdo oscuro que no logra despejar. Sin embargo, por primera vez decide tomar una posición activa y le arroja una copa a la cara, continuando, así, el camino de saldar deudas con su pasado. Este será su único acto.

La película, entre la historia de Michel y las imágenes de los científicos, es entonces un "documento fantástico" (126), un "híbrido de documental” (128) así como el relato de Pierre Pain es un cruce entre la voluntad de testimoniar y la presencia de lo fantástico. También en este sentido Actualidad condensa su propio relato. Los recuerdos de Pain permanecen atrapados en la experiencia traumática de la Gran Guerra, que sin ser

\footnotetext{
Revista Iberoamericana, Vol. LXXX, Núm. 247, Abril-Junio 2014, 493-510 ISSN 0034-9631 (Impreso) IISN 2154-4794 (Electrónico)
} 
explícita retorna en sus pesadillas. Su narración se ancla en dos sitios, por un lado en el registro de los acontecimientos, en el ámbito de lo real, con la necesidad de expresar con detalles todo lo que sucede durante el mes de abril, por París, en un otoño lluvioso. Esa voluntad de testimoniar se exhibe en la constante y prolija referencia a fechas y horas. Las fechas y horarios, casi como las entradas de un diario o un registro, se reiteran con la frágil confianza de dar verosimilitud al relato, por ejemplo "la noche del 7 al 8 de abril” (53), "a las tres menos cinco de la tarde" (91) "a partir del lunes 11 de abril" (150), etc. A esto se le suma el "Epílogo de voces” que, como un diccionario biográfico, informa los destinos de los personajes involucrados en la novela.

Asimismo, todo su relato está impregnado de visiones y pesadillas. Hay una zona indecible que busca decirse, una zona oculta que busca salida en los pliegues de la memoria y es el elemento fantástico el que permite traducir ese doblez, ya que implica hacer visible lo que no se ve, articular lo que no se dice. Lo fantástico opera como un dispositivo sedicioso dentro del relato, es lo que subvierte, altera, corrompe el ordenamiento del discurso y, como afirma Rosemary Jackson en su estudio sobre lo fantástico, perturba "las leyes de la representación artística y las reproducciones de lo 'real' en la literatura” (12).

Este cruce entre ficción y realidad caracteriza la narrativa de Roberto Bolaño. Personajes y hechos reales se fusionan con un mundo ficticio, juntos conjuran nuevas lecturas de lo real. Hay una voluntad testimonial que pugna por reponer la violencia latinoamericana y otros horrores de la historia (aquí está la Europa fascista y nazi), pero esta pulsión por lo real está constantemente amenazada por los fantasmas que la misma barbarie provoca, sus huellas, sus vacíos, sus silencios. Bolaño rearma ciertas zonas de la tradición latinoamericana ligadas al testimonio, lejos del protocolo genérico, para fraguar nuevas formas de anclar lo real en el relato. Frente a la tradición caribeña de lo real maravilloso, elige retomar lo fantástico rioplatense de espectros y pesadillas.

Los pasajes oníricos del relato de Pierre Pain siguen los modos del guión cinematográfico (hay escenas, primer plano, bastidores), imprimiendo una sensación de realidad simulada en un constante vaivén en el que Pain oscila entre realidad y ficción. Además, esta zona paraxial entre pasado y presente, entre lo real y lo onírico está habitada por la imagen de un desconocido. “¿Quién es ese hombre? ¿qué busca?” (54) se pregunta. Es alguien que acecha, cuya presencia se percibe en todo el texto a través de los guiños del relato a la novela de espionaje. En una de sus pesadillas hay un "jefe", "agentes" (54) que se identifican con los españoles que persiguen y vigilan a Pain y a Vallejo.

Otro espacio revelador (junto con el cine) es el almacén industrial, cuyos pasillos convergían en el centro cual laberinto (101). Allí se pone de manifiesto un dolor (pain) interno que pugna por emerger; un otro que hace que Pain ya no sea el mismo. Después de un confuso episodio en un prostíbulo, donde lo invitan a presenciar un acto de pornografía (con elementos de un ritual de magia negra) que Pain rechaza, aparece

\footnotetext{
Revista Iberoamericana, Vol. LXXX, Núm. 247, Abril-Junio 2014, $493-510$
ISSN 0034-9631 (Impreso)
} 
en el almacén. Casi a oscuras, se encuentra atrapado en un depósito de herramientas y trastos viejos que lo inquietan: "en el ambiente flotaba algo que no hacía presagiar nada tranquilizador" (100). No encuentra la salida y decide pasar la noche en esa suerte de cementerio de lo que alguna vez fueron herramientas de trabajo. Se acomoda en una bañadera, como si fuera un ataúd (103), comienza a escuchar un sonido que recorre los espacios -“de pronto el ruido se despegó de la pared y empezó a abrirse paso entre los cachivaches" (103)- hasta materializarse primero en pasos, luego en una sombra con hipo. El dolor que siente en el cuerpo es producto de su postura en la bañera, con una fuerte marca simbólica: es la inmovilidad misma, esa incapacidad de actuar, o de hablar, que tanto acosa a Pain ("En dos ocasiones intenté levantarme, en ambas resbalé, como si el destino no quisiera dejarme correr el más mínimo riesgo” [105]). Otra vez, lo bloquean la pasividad y las imágenes de "fugas y decepciones" (105) que asedian su presente. Cuando despierta, su actitud cambia y decide terminar con algo, "se acabaron las calesas que no van a ninguna parte” (106). Entonces llama a su viejo amigo monsieur Rivette, siguiendo "impulsos desconocidos. Sentía una cólera vaga, una ligera sensación de estafa que poco a poco, como un taxidermista, me iba acorazando por dentro" (109). Aquí reitera la decisión de actuar y, como ocurrió luego del cine frente a su ex colega Pleumer-Boudou, tiene que ver con otro vínculo del pasado -en este caso, Rivette-.

El desconocido ¿era la silueta de Vallejo o la suya propia que lo acechaba desde el pasado? ¿de quién era el hipo insistente, esa voluntad afásica de la palabra atragantada? La clave aparece luego en la conversación que sostiene con Rivette. Aquí hay algo del pasado que tiene que resolverse pues, sin dejar en claro qué fue lo que sucedió entre ellos, hay indicios de una situación traumática que padeció con su grupo de amigos, “¿por qué pienso en ellos? [...] son como fantasmas” (109), confiesa. Tiene que romper los vínculos con sus antiguos “compañeros de viaje, aprendices de brujo” (110) (remite al ritual sangriento del prostíbulo) y pareciera que Pain intenta asumir una culpa o responsabilidad, “estamos todos implicados en este infierno” (111), acusándolo a Rivette de pretender inocencia y estar al margen. Pero también reflexiona: "el viejo y yo éramos semejantes no sólo en nuestra disposición frente al laberinto sino también en nuestra común condición de espectadores” (111). Como Michel, hay una culpa que no se asume.

La condición de "espectador" es otra constante en la novela. Es la actitud pasiva de Pain y está relacionada con otro motivo, el de la salvación. Pierre no puede salvar al esposo de madame Reynaud, ni tampoco a Vallejo, y aunque necesita salvarse a sí mismo no logra salir de su condición de espectador, de su imposibilidad para actuar. Por eso se reitera la imagen del sacrificio, como portador de la salvación, por momentos vinculado a la violencia (como la escena en el prostíbulo donde el entretenimiento consistía en ver a una prostituta 'ofrendada', rodeada de varias gallinas muertas y sangre); pero también tiene las marcas de un ritual que es necesario llevar a cabo (en Actualidad, hay una imagen de Michel frente a lo que parecía una "piedra de sacrificios aztecas” (131)); y con todas

\footnotetext{
Revista Iberoamericana, Vol. LXXX, Núm. 247, Abril-Junio 2014, 493-510 ISSN 0034-9631 (Impreso) ISSN 2154-4794 (Electrónico)
} 
sus implicancias religiosas, la necesidad de salvación asoma acompañada de la idea de culpa o deuda. Es también en el cine donde Pierre siente una suerte de revelación: “Hay un inocente de por medio. Pensé: el sudamericano va a pagar por todos” (128).

Pain se perturba y refuerza su condición de espectador cada vez que se encuentra con ese ser misterioso y a medida que avanza el relato la silueta tiene diversas identidades -Vallejo, Pierre Pain, su pasado-. En una ocasión, espía desde lo alto de una ventana a los médicos de la clínica Arago y sospecha algo peligroso, un secreto, "busqué el interruptor, guiado por un impulso irracional, dar la luz, enseñarme. Confirmar sin asomo mi presencia, mi asistencia, un espectador humilde pero puntual” (149). Pero la luz no funciona y él continúa entonces en su posición distante, al margen de toda acción.

El tercer espacio significativo es la clínica donde está internado Vallejo, percibido como un laberinto con luces que parpadean, al cual Pain entra no sólo para salvar al poeta sino para tramitar los conflictos con su pasado. “¿Buscaba a Vallejo o a otra persona?” (52), se pregunta por los pasillos circulares del hospital. Allí tiene otra experiencia similar a la que vivió en los otros lugares, en el cruce onírico con el pasado, durante la segunda vez que visita el hospital y le impiden ver a Vallejo. Pierre decide ingresar como un desertor, el "que hubiera podido ser de no mediar el gas” (142). Como quien ingresa a un campo enemigo, entre un espía y un prófugo, se "refugia” en un baño, luego decide buscar a Vallejo sabiendo que jamás encontraría su habitación, recorre las galerías interminables, y se pierde (144). Es allí donde repentinamente percibe una imagen del pasado "vi aquello al final del pasillo, como si todo el tiempo hubiera estado allí esperándome. Era apenas una silueta confusa [... ] una pesadilla catapultada de golpe desde la infancia” (144). Las manos de Pain tiemblan, la silueta también; inmediatamente sale corriendo. Luego, nos dice que todo volvió a la normalidad, sus días continúan entre depresivos y desesperados, “aceptando la pena” (150). Así el recorrido por estos tres espacios cerrados manifiesta una tensión entre la búsqueda por tramitar una deuda con el pasado y la dificultad de articular una memoria que permita seguir adelante, “crecer”. ${ }^{1}$

\section{HIPERESTESIA Y MELANCOLÍA: UNA IMAGEN DE ESCRITOR REVISITADA}

Pierre Pain encarna al sujeto melancólico, atormentado por una sensibilidad exacerbada que no es ajena al contexto histórico que enmarca la novela. Es un digno pariente de algún personaje de Edgar Allan Poe, o quizás su reescritura. En el intertexto explicitado en el epígrafe (Revelación mesmérica) el narrador del relato de Poe, P., documenta una experiencia hipnótica con el Sr. Vankirk, un enfermo terminal. Bolaño no sólo retoma a Poe al incluir en la novela el tema del mesmerismo, sino que nombra

\footnotetext{
1 Aquí creo necesario notar que Pierre Pain, es también una traducción del eterno joven, también atado a una imposibilidad (crecer: 'hacerse responsable’): Peter Pan. 
a su narrador Pain y lo caracteriza con los rasgos que podrían describir a un personaje del escritor estadounidense: nervios crispados, alertas, el sensorium exaltado, entre lo real racional y lo irreal.

Esta hipersensibilidad resignifica una figura de artista característica de fines del siglo xIx. Bolaño recoloca al escritor decimonónico en una urbe sitiada, ante la inminencia de la guerra. La hiperestesia que caracteriza al artista ante los estímulos de una modernidad inminente se resemantiza frente a una coyuntura histórica que sólo respira violencia. Ya no está el flâneur que se pierde en la multitud en busca de vivencias novedosas. Pierre Pain recorre una ciudad vacía, entre el miedo y el peligro, habitada por fantasmas. Es la percepción del narrador la que impregna el relato de un suspense que crece gradualmente:

[...] había algo que no calzaba, que intuía en los silencios de Madame Reynaud, en mi propio estado sensorial, alerta por razones que desconocía. Un malestar extraordinario subyacía detrás de las cosas más nimias. Creo que vislumbraba el peligro, pero ignoraba su naturaleza. (23)

A esta actitud de extrema sensibilidad Poe la denomina "percepción mesmérica", en ella se "percibe con agudeza y refinamiento, y por vías presuntamente desconocidas, cosas que están más allá del alcance de los órganos físicos”(Poe). Es la imagen de artista que todo lo aprecia, quien percibe más de lo visible. Pierre Pain distingue los olores de la noche "como si algo se estuviera moviendo por las calles" (51), su cotidianidad se ve interrumpida y busca comprender deambulando por calles vacías, "por momentos me ganaba la melancolía y a los pocos metros volvía a estar sereno, dueño de una tranquilidad atemporal, ajeno a cualquier sobresalto. Pero el temor, lo sabía, seguía allí, incorpóreo y tenaz" (77). Un sentimiento de peligro y desconcierto lo invaden constantemente y se intensifica con los datos externos, como esos espacios oscuros por los que Pain transita en París, lluviosa y desierta, en vísperas de la Segunda Guerra.

Esta hipersensiblidad pareciera ser una secuela de las experiencias traumáticas que el protagonista vivió durante la Gran Guerra. Pain recibe una pensión como inválido, “a los veintiún años me quemaron los dos pulmones en Verdún. Los médicos que me recogieron no supieron nunca cómo logré mantenerme con vida” (84), y su presente está signado por el horror de una guerra que no eligió. Es un pobre estudioso y practicante de las ciencias ocultas, quien rechaza a la sociedad que "tan tranquila [lo] puso en el trance de morir” (84). Pain encarna las ruinas que la guerra dejó, él mismo decide dedicarse a la ciencias ocultas para "empobrecerse sistemáticamente" (85).

La clínica donde agoniza Vallejo es como una "galería de arte" (34), "los blancos pasillos se sucedían como páginas de un libro escrito en lengua extranjera” (143), allí hay un enigma por descifrar, algo que tiene que ser dicho y es en la clínica donde Pain empieza a vislumbrarlo. El estado de Vallejo refracta en su interioridad y las pesadillas

\begin{tabular}{l} 
Revista Iberoamericana, Vol. LXXX, Núm. 247, Abril-Junio 2014, $493-510$ \\
\hline ISSN 0034-9631 (Impreso)
\end{tabular} 
aumentan. Si bien parece siempre un espectador confuso, Pain también es un medium, ("a mi mente llegaban escenas y voces ... que nada tenían que ver con mis propios fantasmas, aunque de manera fortuita me hubiera convertido en el receptor" [52]) un radioaficionado que captura otras voces, "un infierno de voces” (52). Padece una lucha agónica entre el silencio, el olvido, la posibilidad de hablar (el hipo) y el medio del arte para rearticular las voces del pasado, de los otros. Es por ello que en un momento Pain se ve como un radiotransmisor (sus sueños estaban compuestos por "voces, balbuceos, sonidos guturales” [52]) que necesita buscar la frecuencia adecuada para comunicar, para significarse.

Pain ha tenido una experiencia traumática en la Gran Guerra, con sus colegas y no la ha tramitado, por lo cual se le convierte en pesadilla, lo tiene atrapado, intenta salir de ella, pero no puede convertirla en palabra. El silencio y la condición de espectador también se conectan, en un doble juego en el que Pain se siente víctima y culpable. Cuando los españoles le pagan para que no acepte el trabajo que le pide Madame Reynaud, Pierre no admite la posibilidad del soborno, porque no se reconoce con ningún tipo de culpa. Si bien todavía no había aceptado la propuesta, sabía que no podría rechazar a Madame Reynaud, pues estaba en deuda con ella al no haber podido salvar a su esposo. Los españoles le proponen el olvido "queremos que se olvide de todo" y ese olvido permite "la armonía" (42). Pain acepta ese olvido, aunque no llega a comprender mucho lo del soborno porque se siente inocente. De alguna manera, aceptar el dinero es una herramienta para destrabar el olvido y acceder al reconocimiento de que es partícipe o fue partícipe de algo (“cogí el dinero ... sólo por no bloquear ... el orificio” [49]). A partir de este episodio, sus pesadillas van a ser más recurrentes. Los fantasmas del pasado van a regresar aunque Pain dice que no puede hacer memoria (45).

En este contexto la figura agonizante de César Vallejo funciona como un espejo del mismo Pain. Vallejo y su hipo representan su situación, su incapacidad de hablar. La clínica y el almacén como espacios de la memoria devienen también espacios para la palabra. En varias ocasiones - diseminadas por toda la novela- también Pain aparece encerrado en el silencio. Sueña que alguien le "tapaba con suave y obstinada autoridad la boca” (27). ¿Cómo si pretendiera ahogarme? ¿Como si pretendiera obligarme a permanecer en silencio?” (28). Los pasajes oníricos insisten en la imposibilidad de la palabra. Pain intenta decir "que en alguna parte de la ciudad hay un hombre enfermo, pero me quedo con la boca abierta, incapaz de pronunciar un sonido cualquiera" (56), "Siento que me quedo mudo" (57). Cuando Pain ve por única vez a Vallejo, este "se revolvió y abrió los labios pero no llegó a articular palabra” (62), sólo su hipo rasga el silencio, débil y calmo. Pain realiza unos pases de energía y siente un atisbo de esperanza, ¿podrá sanar a Vallejo? Pero sólo el hipo desaparece y retumba ahora en su cabeza, Vallejo permanece inmóvil, hundido en su mudez.

Las "vidas" de Pierre Pain y Vallejo se cruzan no por azar sino -en "términos

Revista Iberoamericana, Vol. LXXX, Núm. 247, Abril-Junio 2014, $493-510$
ISSN 0034-9631 (Impreso) 
mesméricos”- por atracción magnética. Ambos comparten una experiencia común: el horror de la guerra, el resabio de la derrota. No son héroes condecorados, sólo son sobrevivientes olvidados. La figura ficcionalizada del poeta peruano incorpora lo que Idelber Avelar (2000) denomina una alegoría de la derrota. En Vallejo confluyen el ímpetu vanguardista, el espíritu militante y una extrema sensibilidad al sufrimiento que prevalece hasta el final de sus días. Para Bolaño, Vallejo no muere sino de tristeza, de soledad, con la palabra derrotada aunque insistente: es el hipo, espasmódico, molesto. La poesía de Vallejo enmarca esta necesidad/imposibilidad, basta recordar las líneas de "Intensidad y altura” (Poemas humanos): "Quiero escribir, pero me sale espuma,/quiero decir muchísimo y me atollo;/no hay cifra hablada que no sea suma,/no hay pirámide escrita, sin cogollo"; "Quiero hablar del mar, pero me sale espuma” (Spiller 146). El deseo y la impotencia, la dificultad y el esfuerzo por la palabra se intensifican en Bolaño: de la suavidad de la espuma al golpe incisivo del hipo. Las figuras espectrales de Pain y Vallejo reflejan los residuos de las utopías, las ruinas de la historia en un contrapunto que une Europa con Latinoamérica.

Pierre Pain se debe un encuentro con el pasado, pero sus recuerdos del horror se cruzan con las señales de un presente poco tranquilizador, augurando peores acontecimientos. El enigma en torno al estado de Vallejo, junto con el acecho de los dos españoles cual heraldos negros, suman a la atmósfera de muerte en el marco de la Guerra Civil española un panorama venidero que tendrá su punto álgido con el nazismo que asolará a Europa. Llegan noticias sobre España de muertos a millares, de armas nuevas, y en un bar se comenta "los malditos alemanes ensayan su arsenal" (81); Pain recuerda a los médicos que lo atendieron y ve "detrás de sus rostros [...] jirones de un hospital de campaña y, más atrás aún, los pliegues de un cielo gris, el presagio de la tormenta” (84). Entonces todas las señales diseminadas en el texto de que algo siniestro va a ocurrir confluyen en el anuncio de la Segunda Guerra.

Como en otras obras de Bolaño, los relatos intercalados, los sueños o visiones de los personajes alumbran nuevos haces de significados. ${ }^{2}$ En una ocasión, Pain conoce en un extraño café a dos hermanos, artistas de miniaturas, que reconstruían catástrofes en grandes peceras minadas de cadáveres, "donde sólo ondeaban las banderas de la muerte” (71). En una de las peceras, una locomotora estaba rodeada de "puntitos negros": "cabezas seccionadas" (71), no resulta casual que el tren encargado especialmente a Alemania se denomine Meersburgo Express. En esa ciudad alemana muere Franz Anton Mesmer, así el horror de la guerra y las ciencias ocultas se interrelacionan. El vínculo entre la ciencia y la violencia (recordemos que para Plemeur-Bodou el mesmerismo es útil en los interrogatorios de prisioneros y espías, y el conflicto de Actualidad gira en torno a

2 Ver, por ejemplo, las lecturas de Nocturno de Chile y Estrella distante, Aguilar (2008) y Fischer (2008) respectivamente.

Revista Iberoamericana, Vol. LXXX, Núm. 247, Abril-Junio 2014, 493-510
ISSN 2154-4794 (Electrónico) 
esta cuestión) también se extiende a las relaciones entre el mal, la destrucción y el arte. ${ }^{3}$ De la conversación con estos hacedores de cementerios marinos surge, inesperada y sin una razón aparente, una palabra iluminadora: anamnesis.

Se trata de la memoria en tanto anamnesis y no mnemne: de la memoria en construcción, en movimiento, en actividad, y no de la memoria ya instalada en los imaginarios comunitarios y en los textos de la historia. Yerushalmi (1996) distingue la mnemne o memoria (aquello que permanece esencialmente ininterrumpido, continuo, igual a sí mismo) de la anamnesis o reminiscencia como "la reminiscencia de lo que se ha olvidado" (21), que, por ello mismo, precisa un proceso de elaboración, una recuperación de lo olvidado para el presente. Insistir en imágenes de lo crepuscular, lo funeral, reincidir en visiones donde se respira una violencia latente es apelar a una memoria que, con palabras de Reyes Mate (2006), privilegie la mirada del sujeto que sufre. En línea benjaminiana, Mate afirma que "la memoria tiene que ver con el pasado ausente, el de los vencidos” (45); es decir, es la expresión de la derrota, de lo desechado por la historia. Señala que

un pasado será bien recordado si se concreta en un valor, en un patrimonio, que nos saca a nosotros, sus herederos, de penas. Ese es un pasado apreciado. Por eso será de mal gusto que alguien saque de la tumba a esos perdedores que no legaron nada porque a ellos mismos se les despojó de todo. [...] Todo el mundo prefiere recordar las divertidas canciones de Lili Marleen y olvidar las ruinas humeantes de Berlín. (48)

Así, Pierre Pain sabe que "las bombas, los gases, las enfermedades nos reventaban a nosotros, una tropa atemorizada y embrutecida compuesta de campesinos, obreros, pequeñoburgueses ilusos”(84). El presente de Pain está impregnado de su pasado en las trincheras, tiene en su interior un nudo que no logra liberar. Y la misión de salvar a Vallejo se le manifiesta como una oportunidad casi redentora, descrita como un "movimiento" (se abre ante Pierre "Abril, un nuevo ciclo vital” [25]) como si algo que antes estuviera trabado ahora pudiera comenzar a fluir.

César Vallejo se muere solitario, en una clínica laberíntica, atrapado entre el hipo y el silencio, sólo es un "minúsculo y quebradizo cuerpo humano". El poeta vanguardista, comprometido con la República, que estuvo en el frente de Madrid, se encuentra en un "estado anormal cuyas manifestaciones se parecen estrechamente a las de la muerte"(Poe). Vallejo no padece enfermedad alguna, sufre el ahogo de no poder pronunciar palabras, condición que Walter Benjamin describe en su tan citado ensayo sobre el narrador y la experiencia. El estado en que se encuentra Vallejo, semejante a esa condición mesmérica

3 Cabe mencionar otras obras de Bolaño donde las relaciones entre el arte y el mal, la violencia son un núcleo fundamental de la trama, como en Estrella distante, Nocturno de Chile, La literatura nazi en América, "Otro cuento ruso" en Llamadas telefónicas.

ISSN 0034-9631 (Impreso) 
que Poe describía, entre la vida y la muerte, es análogo a la situación de Pierre Pain en conflicto con el pasado y con un presente que no olvida.

El mesmerismo como doctrina define al método terapéutico mediante el cual pueden curarse males gracias a una fuerza universal. Vinculado al magnetismo y la hipnosis identifica también al estado de un individuo bajo la influencia de la voluntad de otra persona. La condición mesmérica interrumpe las impresiones corporales, físicas, externas y permite la búsqueda de otros medios de expresión, etéreos, internos. Un texto de William Q. Judge, co-fundador de la Sociedad Teosófica, explica:

Al separar a este ser del cuerpo externo al cual está atado, lo privaremos temporáneamente dela libertad, convirtiéndolo en el esclavo del operador. Sin embargo, los mesmerizadores, saben muy bien que el sujeto puede sustraerse, y a menudo se sustrae, al control, sorprendiéndolos y asustándolos. Todos los mejores escritores occidentales lo atestiguan. (Judge $)^{4}$

En Monsieur Pain Bolaño relee el mesmerismo en la relación de Pain con su pasado. Sus recuerdos controlan su presente y, por más que intente, no puede sustraerse a ellos. Aquí el mesmerismo señala la imposibilidad de convivir con el pasado para construir una memoria, ya que el mesmerismo sería "un velo", que sirve "a un propósito: desfigurar, ocultar..." (88). Para comprender esto es necesario acudir al intertexto de Edgar Allan Poe que resulta iluminador: por un instante, Pain se ve a sí mismo como un "Dr. Templeton menos memorioso" (89). En el relato de Poe, “A Tale of the Ragged Mountains", el doctor Templeton es un practicante del mesmerismo que intenta salvar la vida de un paciente para redimir sus culpas por no haber evitado la muerte de un viejo amigo. Aquí, el presente convoca al pasado a través de la figura de Bedloe (nuevo paciente de Templeton) que remite a Oldeb (su viejo compañero); Templeton no consigue salvar a ninguno. Su antiguo amigo Oldeb muere por una flecha envenenada, y Bedloe también muere envenado. La memoria de Oldeb lo persigue y el doctor no puede conciliar con su pasado. No hay posibilidad de salvación, no es posible saldar la vieja deuda. El mesmerismo entonces es una vía para acceder al pasado pero sin posibilidad de exonerar sus fantasmas.

Si bien Pain cree que podrá curar a Vallejo se enfrenta a obstáculos, fuerzas extrañas que lo impiden, y ya no podrá verlo más. El fracaso lo alcanza cuando Madame Reynaud, quien para mayor decepción de Pierre regresa con novio, le comunica la muerte del poeta peruano. Luego sabemos que el destino de Pain fue entre espacios marginales, con números circenses y esotéricos entre prostitutas y traficantes. Ni siquiera funciona una última posibilidad de redimirse: intenta la lucha antifascista de la Resistencia pero

$\overline{4}$ Publicado en 1892 en la revista Lucifer editada por Helena Blavatsky desde 1877.

ISSN 0034-9631 (Impreso) 
todo queda en la nada y Pain termina sus días aplicado a la lectura de "manos manchadas de sangre, manos de verdugos y de putas siniestras, de vividores y de traficantes del mercado negro" (170).

Si, como sostiene Roland Spiller (2009) el 11 de septiembre de 1973 "marcó un trauma dentro de la historia del fracaso de las utopías en Latinoamérica, en el siglo xx” (145), Monsieur Pain, gestada a principios de la década del ochenta, se presenta como una reflexión sobre la derrota en Chile, hilvanando los grandes acontecimientos históricos determinantes de la memoria colectiva del siglo xx: la Guerra Civil española y el nazismo; en un vaivén de acontecimientos signados por el horror anclado en la civilización occidental. Las políticas violentas, las dictaduras, el terrorismo de Estado y el fracaso de las utopías no conocen fronteras (Spiller 146). Bolaño reflexiona sobre el mal y la violencia desde Latinoamérica, a partir de las dictaduras de los setenta en el Cono Sur, hacia Occidente. Obras como Estrella distante, La literatura nazi en América Latina se muestra un imaginario apocalíptico que recorre las dictaduras y posdictaduras latinoamericanas, junto con los totalitarismos europeos. Son los núcleos de una constante obsesión por desentrañar las formas del mal que marcaron al mundo occidental, que culmina en la gran novela póstuma: 2666.

\section{Melancolía y POSDictadura}

Monsieur Pain es también una novela de la posdictadura en tanto despliega lo que Idelber Avelar (2000) denomina su "terreno afectivo": la experiencia de la derrota, el carácter interminable del duelo, la melancolía. Nombrar el presente como posdictadura implica recordar que es "producto de una catástrofe pasada", es marcar al tiempo presente como heredero de un conflicto no asimilable a denominaciones como "tiempos de 'democracia, [...] 'estabilidad', [...] 'gobernabilidad'”, expresiones que intentan ocultar esa "catástrofe”. Para Avelar se impone una "mirada que aspira a ver en el presente lo que a ese presente excede -el suplemento que el presente ha optado por silenciar [...] su condición postdictatorial, su fantasmagórico duelo irresuelto” (37).

La reflexión sobre las características y tendencias del pensamiento en la postdictadura -la derrota, el duelo, la melancolía - forma parte de la agenda de debates abierta con la apertura democrática en el Cono Sur. Dentro de las posibilidades de sobreponerse a la pérdida del horizonte utópico a través de un pensamiento crítico, la posición melancólica se lee como ruina (Moreiras 1993), incapacidad (Galende 1998), paralización (Richard 2004); para la crítica cultural, la actitud melancólica de la posdictadura pierde politicidad. Sin embargo, Avelar advierte que el contexto posdictatorial de la derrota no puede ser sino melancólico; y el duelo, al no resolverse, demanda una memoria activa, en constante

\footnotetext{
Revista Iberoamericana, Vol. LXXX, Núm. 247, Abril-Junio 2014, 493-510 ISSN 0034-9631 (Impreso) ISSN 2154-4794 (Electrónico)
} 
devenir presente, presencia. ${ }^{5}$ Entonces, hay la posibilidad de una melancolía crítica como antídoto contra cierto progresismo optimista (Avelar 295), contra las fijaciones de sentido que derivan en 'memorias oficiales' cercanas a la amnesia, edificadas con el silencio tranquilizador de un pasado sellado.

En línea con la propuesta de Avelar, Christian Gundermann (2007) articula una nueva lectura del par freudiano duelo/melancolía con teorizaciones como las de Judith Butler, Paul Virilio, Abraham y Torok para rebatir las intervenciones críticas que han considerado la actitud melancólica de la posdictadura como síntoma de la inacción, el retraímiento o la ineficacia. Insistir en la melancolía como condición de posibilidad de una producción cultural crítica durante la postdictadura es negarse a pensar el pasado como instancia clausurada. Es decir, implica una resistencia que, lejos de estancarse en las utopías de los sesenta, se instala en el presente como "continuidad de la dictadura [...] en todos los niveles de la sociedad y sobre todo en el plano económico” (Gundermann 165).

El potencial político y estético de la denominada "melancolía combativa" se delinea desde los aportes críticos de Judith Butler y su resignificación del mito de Antígona. La resistencia a las leyes del poder político amnésico que la figura de Antígona impone al enfrentar a Creonte da lugar a una "melancolía combativa" que se niega a aceptar el duelo, pasivo y privado (frente a la insistencia pública en su derecho a enterrar al hermano muerto). Gundermann relee la operación de Butler sobre la figura de Antígona desde la lucha de las Madres de Plaza de Mayo en Argentina y opone un trabajo melancólico frente al trabajo de duelo que para algunos críticos, como Avelar, se vuelve imperativo en la posdictadura. Señala que "la productividad del duelo no parece sino reestablecer el orden dado, parece relegar a la esfera privada los reclamos de la memoria” (54). Sin embargo, cabe destacar que, como advierte José Amícola (2009), "la imposibilidad del duelo no lleva necesariamente a la melancolía”, un binarismo excesivo reduciría la problemática de la memoria en lugar de desplegar diversos modos de abordarla. Para que exista una actitud melancólica hace falta un tono, un modo de ver que no excluye otras perspectivas, sino más bien constituye una elección.

Los personajes de Bolaño son melancólicos y sus narraciones tienen esa inflexión melancólica que lo colocan en una tradición latinoamericana desde la cual, trasvasando etiquetas y fronteras, da lugar al relato de las derrotas de los setenta. Desde Latinoamérica hilvana, a su vez, otras derrotas históricas: está Pierre Pain en la Francia acechada por la ocupación nazi, está César Vallejo evocando una Sudamérica vencida. Explica Roger

5 Señala Avelar en una entrevista: "Si no hay melancolía no hay trabajo, lo que hay es pura técnica, puro adaptarse a la vorágine que llamamos progreso, puro automatismo. Sólo hay praxis genuina cuando hay desolación ante la miseria, la catástrofe. La operación consiste en tomar duelo y melancolía como un par conceptual en el cual uno es la manifestación de la no resolución del otro, y transformar ese polo, la manifestación de lo irresuelto, en condición de posibilidad del término originario mismo" (Avelar en Maldonado) Ver también Alegorías de la derrota.

\footnotetext{
Revista Iberoamericana, Vol. LXXX, Núm. 247, Abril-Junio 2014, 493-510 ISSN 0034-9631 (Impreso) ISSN 2154-4794 (Electrónico)
} 
Bartra:

\begin{abstract}
La melancolía se convierte en una red mediadora que comunica entre sí a seres que sufren o intentan comprender la soledad y el aislamiento, la incomprensión y la dislocación, la transición y la separación. Así, podemos suponer que quienes participan del canon de la melancolía se entienden y se desentienden, se comunican en la soledad y codifican el misterio de la separación. (Batra)
\end{abstract}

En los textos de Roberto Bolaño la melancolía es una nota radical de la escritura en tiempo presente. Luego de la caída de Allende ¿desde dónde se puede producir sino desde la melancolía? Siguiendo el esquema freudiano, la melancolía -frente al duelo- conlleva una culpa atrapada en el recuerdo. Esto provoca la inmovilidad, la imposibilidad de acción ante la pérdida. El recuerdo de esa pérdida convierte al que sufre en un espectador. Esta pasividad externa también es un motor de búsqueda de sentido. La melancolía dispara la necesidad de articular una memoria y el arte da cuenta de ello. En Monsieur Pain Bolaño encarna la protofigura de escritor melancólico de los noventa en la agonía de Vallejo quien muere de dolor (pain) junto a la España republicana, en una Europa donde se palpita el fascismo. Está también en Pierre Pain, en esa imposibilidad que lo caracteriza: con trabas en el recuerdo, en la acción. Es esta condición la que lo lleva a fracasar.

Sin embargo, la conjunción entre melancolía y fracaso parece funcionar en el plano de la praxis. Pain es un mero espectador, Vallejo muere de dolor ante la inminencia de una lucha perdida. Pero la fuerza de la palabra manifestada en el hipo insistente, en las voces que Pain canaliza, da cuenta de una zona que pugna por emerger. Es la melancolía en su presencia más productiva y crítica a la vez, anunciando que ya no hay heroicidad en el arte; el artista militante devino artista melancólico porque se ha abierto una herida dolorosa que no será posible suturar.

Entonces para Bolaño la melancolía se vuelve un espacio adecuado para revisar los convulsionados episodios de la historia reciente, para evaluar las experiencias del terrorismo de estado, para recordar algunos episodios de las derrotas de las décadas pasadas en América Latina, e incluso para una autocrítica de la izquierda, de sus utopías y batallas. La melancolía también sirve a una estética, edifica una escritura en el cruce de lo real y lo fantástico que revela una tensión entre la voluntad del testimonio y su propia incapacidad, la imposibilidad de un relato ordenado y racional ante los fantasmas que el mismo relato desata.

Si Monsieur Pain prefigura el espacio posdictatorial (Basile 2000) asume que la posdictadura no es la época posterior a la derrota, porque "la derrota todavía circunscribe nuestro horizonte, no hay posterioridad respecto de ella” (Avelar 29). Sin panegíricos ni mitologías, se trata de hacerse cargo de una generación entera de jóvenes de entre dieciséis y veintitantos años que no están, a diferencia de muchos de sus referentes y

Revista Iberoamericana, Vol. LXXX, Núm. 247, Abril-Junio 2014, $493-510$
ISSN 0034-9631 (Impreso) 
líderes que sí sobrevivieron, una generación que entregó su juventud a favor de una causa, como Bolaño relata,

\begin{abstract}
luchamos a brazo partido, pero tuvimos jefes corruptos, líderes cobardes, un aparato de propaganda que era peor que una leprosería, luchamos por partidos que de haber vencido nos habrían enviado de inmediato a un campo de trabajos forzados, luchamos y pusimos toda nuestra generosidad en un ideal que hacía más de cincuenta años que estaba muerto. (Bolaño, Entre paréntesis 37)
\end{abstract}

Las novelas de Bolaño se anclan en este "territorio afectivo" de la posdictadura chilena hurgando en el duelo y la melancolía, como en Nocturno de Chile, pero también extienden ese duelo a la geografía más amplia de América Latina para perseguir allí las huellas de la derrota de los ideales sesentistas, como en Amuleto o Los detectives salvajes. Su proyecto creador se inscribe en los desplazamientos desde la década de los sesenta, fuertemente marcada por la revolución cubana y las narrativas del boom latinoamericano, hacia el fin de siglo sacudido por las experiencias de las dictaduras y por la emergencia de nuevas escrituras que intentan procesar los significados de esta época “crepuscular”. Las huellas de la violencia exigen nuevos modos de abordar lo “real” porque la experiencia adquirió dimensiones inefables; una estética de la melancolía incorpora la derrota al aceptar que “Después del 11 de septiembre ya no nos estaría dada la posibilidad de creer en el proyecto de redención por las letras” (Avelar 25).

La narrativa de Bolaño se posiciona en el campo literario chileno de los noventa desde un margen ambiguo, que el mismo autor ha incentivado a partir de una imagen de escritor irreverente, poco adepto a las instancias de legitimación de-algunos de-sus pares chilenos: talleres, entrevistas, cócteles editoriales. Esta imagen se desdibuja, en parte, al confirmarse el lugar central que ocupa en las letras latinoamericanas, no sólo a partir del éxito editorial de sus obras, sino de las lecturas realizadas por la academia y la crítica, a pesar de que esta centralidad se muestre parcial en Chile, en tanto, en un principio, sólo es reconocida por unos pocos. ${ }^{6}$ No es casual que en los dos textos que ofrecieron un primer panorama sobre la llamada Nueva narrativa chilena, como el del crítico Rodrigo Cánovas, Novela chilena: nuevas generaciones. El abordaje de los huérfanos (1997) y la compilación de ponencias leídas en el seminario organizado

6 Al respecto, la crítica chilena Patricia Espinosa aclara: “Acostumbrados a un campo cultural donde cada persona que tiene una cuota de poder lo ejerce con violencia segmentadora, decidí hacer un gesto obviamente retrógrado. La idea ha sido invitar, incluso a los supuestos 'enemigos' de Bolaño, y exponer sus escrituras a la confrontación. No resulta casual, en todo caso, que un importante número de narradores y críticos se haya negado a participar bajo mil y a veces entendibles excusas. Gestos que sin duda revelan un miopía extrema, pero cuyas causas profundas tienen mucho que ver con el estado actual del quehacer crítico” (3).

Revista Iberoamericana, Vol. LXXX, Núm. 247, Abril-Junio 2014, $493-510$
ISSN 0034-9631 (Impreso) 
por el diario La Época sobre "Nueva narrativa chilena" (1997), el nombre de Roberto Bolaño sólo se mencione, en esta última publicación, en dos oportunidades.

Bolaño se forjó un lugar incómodo en el campo literario chileno, marcando distancias y rechazos respecto de los "padres” (epígonos del boom latinoamericano y las estéticas de los sesenta y setenta) y los "pares” (desde Diamela Eltit a Alberto Fuguet). Pero además, desde su exilio en España, refunda su linaje literario vinculándose a escritores españoles y latinoamericanos, lo que le permite hablar de las derrotas que recorren América Latina (como la de Tlatelolco, en la novela Amuleto) y trasladarse a otros nudos penosos de la historia (como el nazismo, en La literatura nazi en América, por ejemplo).

Hoy su obra ya ha sido devorada por la industria editorial y la industria académica: en las librerías, sus novelas se agotan rápidamente; en las universidades, congresos y publicaciones abundan estudios especializados. Sin embargo, la construcción del mito Bolaño no alcanza para demoler una escritura inteligente, intensa.

En Monsieur Pain se vislumbran los elementos que otras novelas y cuentos de Bolaño expandirán de una manera u otra: la melancolía; la violencia; misterios que aún en clave de policial-no terminarán por develarse; el escritor pobre; los ideales que naufragan. Un universo que, rebasando operaciones de marketing editorial, nos reta a mirar nuestra historia reciente, sus vestigios desde un presente gris y melancólico, como la Paris por la que deambula Pierre Pain.

Como texto de los comienzos Monsieur Pain establece una continuidad con otras obras de Bolaño y anticipa un tono, un modo visceral de narrar los restos que dejaron las dictaduras de los setenta, y de hurgar en las vísceras de la historia. Lejos de una “evocación nostálgica de la contracultura rebelde de los años 60 y 70" (Castellanos Moya 8) que atrapó a los lectores estadounidenses y formó parte de una estrategia editorial para renovar la visión de Latinoamérica, Bolaño elige tributar a la generación de militantes de izquierda con un relato que es un homenaje-deuda, escrito desde un distanciamiento problematizador y melancólico. No hay la nostalgia de un pasado con sueños de utopía, ni una épica de la resistencia heroica. Por el contrario, la melancolía devela los abismos de la utopía en un presente elegíaco. En la "Nota preliminar” Bolaño cuenta que elige a Pierre Pain y a César Vallejo para empezar a ganarse la vida como escritor, con ambos obtiene los premios más importantes: los del comienzo. "Nunca como entonces me sentí más orgulloso y más desdichado de ser escritor”, confiesa (12). Como señala Said, los comienzos no son sólo una acción, sino, además, una actitud.

Revista Iberoamericana, Vol. LXXX, Núm. 247, Abril-Junio 2014, $493-510$
ISSN 0034-9631 (Impreso) 
BiBLIOGRAFÍA

Aguilar, Gonzalo. “Roberto Bolaño, entre la historia y la melancolía”. Roberto Bolaño. La escritura como tauromaquia. Celina Manzoni, comp., prólogo y ed. Buenos Aires: Corregidor, 2002. 145-151.

Aguilar, Paula. "Literatura y melancolía en el contexto de la posdictadura chilena”. Bolaño salvaje. Edmundo Paz Soldán y Gustavo Faberón Patriau, eds. Barcelona: Candaya, 2008.

Amícola, José. "Perlongher: memoria, luto y melancolía”. VII Congreso Internacional Orbis Tertius. La Plata, 2009. < www.orbistertius.unlp.edu.ar>

Avelar, Idelber. Alegorías de la derrota: La ficción postdictatorial y el trabajo del duelo. Santiago: Cuarto Propio, 2000.

Bartra, Roger. El mito de la melancolía: literatura y ciencia en el siglo de oro. México: Universidad Iberoamericana, 1998. <http://www.fractal.com.mx/F8bartra.html>

Basile Teresa. “Aproximaciones a la posdictadura en el Cono Sur”. Dispositio XXIV/51 (2000): 115-133.

Benjamin, Walter. “El narrador. Consideraciones sobre la obra de Nicolai Leskov”. Sobre el programa de la filosofía futura. 1936. Barcelona: Planeta-Agostini, 1986. 189-211.

Bianchi, Soledad.¿La insoportable levedad...? (imágenes y textos, postdictadura y modernidad en Chile). Santiago: Centro de investigaciones sociales, Universidad Arcis, 1997.

Bolaño Roberto. Entre Paréntesis. Barcelona: Anagrama, 2004. Monsieur Pain. Barcelona: Anagrama, 1999.

Cánovas, Rodrigo. Novela chilena, nuevas generaciones. El abordaje de los huérfanos. Santiago: Universidad Católica de Chile, 1997.

Castellanos Moya, Horacio.

Espinosa, Patricia, comp. Territorios en fuga. Estudios críticos sobre la obra de Roberto Bolaño. Santiago de Chile: Frasis, 2003.

Franz, Carlos. "Nueva narrativas, viejas picas”. Nueva narrativa chilena. Carlos Olivares, ed. Santiago: Lom, 1997. 107-113.

Fuguet, Alberto. "21 notas sobre la nueva narrativa”. Nueva narrativa chilena. Carlos Olivares, ed. Santiago: Lom, 1997. 119-122.

y Sergio Gómez, comp. McOndo. Barcelona: Grijalbo-Mondadori, 1996.

Galende, Federico. "La izquierda entre el duelo, la melancolía y el trauma”. Revista de crítica cultural 17 (noviembre 1998): 28-47.

Gundermann, Christian. Actos melancólicos: formas de resistencia en la posdictadura argentina. Rosario: Beatriz Viterbo, 2007.

Jackson, Rosemary. Fantasy: literatura y subversión. Buenos Aires: Catálogos, 1986. Judge, William. "Mesmerismo” <http://www.upasika.com/docs/teosofia.pdf>

Revista Iberoamericana, Vol. LXXX, Núm. 247, Abril-Junio 2014, $493-510$
ISSN 0034-9631 (Impreso) 
Maldonado, Carlos . “América Latina, ficciones y derrotas”. Entrevista a Idelber Avelar. El Mostrador. 20 ago. 2000. <www.elmostrador.cl>.

Mate, Reyes. "Memoria e historia: dos lecturas del pasado". Letras libres (febrero 2006): 44-48.

Moreiras, Alberto. "Posdictadura y reforma del pensamiento". Revista de crítica cultural 7 (noviembre 1993): 26-35.

Poe, Edgar A. "Revelación mesmérica”. 1844. <www.ciudadseva.com>

Richard, Nelly. La insubordinación de los signos. Santiago: Cuarto Propio, 1994.

“Lo político y lo crítico en el arte: ¿quién le teme a la neovanguardia?”. Pensamiento de los confines. Buenos Aires: Fondo de Cultura Económica, n. 15, diciembre 2004.

Said, Edward. Beginnings: Intention and Method. Nueva York: Columbia UP, 1985.

Spiller Roland. "Roberto Bolaño: fracasar con éxito o navigare necessum est”. Poéticas del fracaso. Yvette Sánchez y Roland Spiller, eds. Tübingen: Gunter Narr Verlag, 2009. 143-173.

Vallejo César. "Intensidad y altura”. Obra poética completa. 1939. Enrique Ballón Aguirre, ed. Caracas: Biblioteca Ayacucho, 1979. 132.

Yerushalmi, Yosef. "Reflexiones sobre el olvido". Yosef Yerushalmi y otros. Usos del olvido. Comunicaciones al Coloquio de Royaumont. Buenos Aires: Nueva Visión, 1996. 13-50.

Revista Iberoamericana, Vol. LXXX, Núm. 247,
ISSN 0034-9631 (Impreso) 